\title{
The biogeochemical behavior of dissolved aluminum in the southern Yellow Sea: Influence of the spring phytoplankton bloom
}

\author{
LI FaMing ${ }^{1}$, REN JingLing ${ }^{1 *}$, YAN Li $^{1}$, LIU SuMei $^{1}$, LIU ChengGang ${ }^{2}$, ZHOU Feng $^{2}$ \& \\ ZHANG Jing ${ }^{3}$ \\ ${ }^{1}$ Key Laboratory of Marine Chemistry Theory and Technology, Ministry of Education, Ocean University of China, Qingdao 266100, China; \\ ${ }^{2}$ State Key Laboratory of Satellite Ocean Environment Dynamics, Second Institute of Oceanography, State Oceanic Administration, Hangzhou \\ 310012, China; \\ ${ }^{3}$ State Key Laboratory of Estuarine and Coastal Research, East China Normal University, Shanghai 200062, China
}

Received July 15, 2012; accepted September 18, 2012; published online October 18, 2012

\begin{abstract}
Many recent studies have investigated the nutrient-type profiles of dissolved aluminum (Al) in the ocean. Significant scavenging of dissolved Al can occur during phytoplankton blooms, but the mechanism remains unclear. The distribution of dissolved Al in the southern Yellow Sea (SYS) was investigated in winter and spring 2009. Following measurements at grid stations during the spring sampling cruise, two drifting anchor surveys of more than $100 \mathrm{~h}$ were conducted to trace the variation of dissolved Al concentration during the spring phytoplankton bloom (SPB). The concentration of dissolved $\mathrm{Al}$ in the SYS decreased from $40 \mathrm{nmol} / \mathrm{L}$ in February to $30 \mathrm{nmol} / \mathrm{L}$ in March and $10-20 \mathrm{nmol} / \mathrm{L}$ in April, while the concentration of Chl $a$ increased from $<2 \mu \mathrm{g} / \mathrm{L}$ in $\mathrm{March}$ to $>4 \mu \mathrm{g} / \mathrm{L}$ in April. The concentration of dissolved Al in the SYS decreased significantly with the development of the phytoplankton bloom, which indicated biological scavenging of dissolved Al from water column. The proportion of dissolved Al scavenged from water column by different phytoplankton species differed at the two drifting stations, with greater removal efficiency demonstrated by diatoms than dinoflagellates. Phytoplankton samples collected from the $\mathrm{Chl} a$ maximum layer were washed with trace metal clean reagent (oxalate-EDTA-citrate, abbreviate as oxalate solution, Tovar-Sanchez et al., 2003) to enable the surface-scavenged (extracellular) and intracellular $\mathrm{Al}$ pools associated with phytoplankton to be differentiated. Thirty-nine to ninetysix percent of the total $\mathrm{Al}$ was found to be existed in the interior pools, which indicated that biological absorption was the important way to scavenge dissolved $\mathrm{Al}$ during phytoplankton blooms in the SYS.
\end{abstract}

dissolved aluminum, distribution, spring phytoplankton bloom, southern Yellow Sea

Citation: $\quad$ Li F M, Ren J L, Yan L, et al. The biogeochemical behavior of dissolved aluminum in the southern Yellow Sea: Influence of the spring phytoplankton bloom. Chin Sci Bull, 2013, 58: 238-248, doi: 10.1007/s11434-012-5512-5

GEOTRACES is an international program to improve understanding of biogeochemical cycles and the large-scale distribution of trace elements and their isotopes (TEIs) in the marine environment. As one of the TEIs, dissolved aluminum ( $\mathrm{Al})$ has been investigated intensively in the Pacific [1-4], Atlantic [5-8], Indian Ocean [9-11], Arctic/Antarctic [12-15], and Mediterranean [16-18]. The concentrations of dissolved $\mathrm{Al}$ show a high variability, ranging from 0.1 $\mathrm{nmol} / \mathrm{L}$ in the surface waters of the Pacific Ocean $[2,3]$ to

*Corresponding author (email: renjingl@ouc.edu.cn)
$174 \mathrm{nmol} / \mathrm{L}$ in the Mediterranean [16]. Sources of dissolved Al to the world's oceans mainly include atmospheric inputs [2,3,7,19-22], fluvial inputs [23-25], and dissolution from sediments [26,27]. Fluvial inputs are negligible because of estuarine removal processes, while the atmospheric inputs are the main source of $\mathrm{Al}$ to the open ocean. Therefore, dissolved $\mathrm{Al}$ in surface water can serve as an ideal tracer for quantifying dust deposition in the open ocean [28-31].

In the surface sea water, $\mathrm{Al}$ has a short residence time of only 4 weeks to 4 years [2]. Processes removing Al from sea water include passive scavenging onto particles [1,2,6,7,32] 
and active biological uptake by diatoms [33-37]. By using a global model of Al cycling, Han et al. [31] estimated the relative importance of the aforementioned two processes on the removal of $\mathrm{Al}$ from surface sea water. Their results indicated that adsorption of $\mathrm{Al}$ on particles dominates the removal of $\mathrm{Al}(\sim 70 \%)$ compared to the biological uptake of dissolved $\mathrm{Al}$ to form the siliceous frustule by diatom accounts for $\sim 30 \%$. They suggested that biological uptake will exceed particle scavenging when diatom biomass is high and dust flux is low, especially in coastal areas having frequent phytoplankton blooms. However, the biological mechanisms of removal of $\mathrm{Al}$ from seawater are not clear. There are two distinct pools of $\mathrm{Al}$ in phytoplankton: that adsorbed extracellularly to the cell surface, and that sequestered internally. Hudson et al. [38] used Ti (III)-EDTA-citrate as a trace metal clean reagent to distinguish between extracellular and intracellular trace metal in marine phytoplankton, and Tovar-Sanchez et al. [39] developed a new reagent (oxalate-EDTA-citrate) to remove surface-bound trace metal, which they successfully applied in a field study of iron.

The southern Yellow Sea (SYS) is a semi-enclosed water body in the western Pacific, bordered by China and the Korean Peninsula. Water circulation in the SYS is characterized by the Yellow Sea Warm Current (YSWC) and currents along the coasts of China and Korea, including the Yellow Sea Coastal Current (YSCC) and the Korea Coastal Current (KCC) [40]. The YSWC transports warm, saline water from the open ocean into the SYS; it is strongest in winter, and disappears or is very weak in summer [41]. The Yellow Sea Cold Water Mass (YSCWM) occurs in the central SYS because of the unique basin and tidal condition [42]. It occurs below $25 \mathrm{~m}$ layer, where it forms a strongly stratified layer, that develops in spring, strengthens in summer and disappears in autumn [43]. Although many rivers empty into the SYS from China and Korea, most terrestrial materials and pollutants from the adjacent land masses enter the SYS via the atmosphere in spring $[44,45]$. Therefore, the spring phytoplankton bloom (SPB) in the SYS usually occurs in April, at that time when Asian dust storms occur frequently [46]. Two mainly phytoplankton types dominate the SPB in the SYS; diatoms and dinoflagellates [47]. As SPBs commonly occur in the SYS without substantial terrestrial input from the adjacent rivers, the SYS is an ideal place to explore the impact of phytoplankton on the biogeochemical behavior of dissolved Al.

Up to now, the biogeochemical behavior of dissolved Al in the SYS is still unclear. Ren et al. [48] made an initial report of dissolved $\mathrm{Al}$ concentrations in the SYS, based on measurements at three separate locations. Ren et al. [49] subsequently reported dissolved $\mathrm{Al}$ concentrations in spring 2007, following a major Asian dust storm and large scale diatom bloom that occurred 4-5 d after the storm. Their results showed that the phytoplankton bloom affected the concentrations of dissolved $\mathrm{Al}$ in the SYS, but the biological removal mechanisms were not investigated. In this study, we assessed variations in dissolved $\mathrm{Al}$ concentrations during the SPB, and investigated the biological mechanisms involved using the oxalate reagent to distinguish between extracellular and intracellular $\mathrm{Al}$ associated with phytoplankton collected in the field. The study contributes to understanding of the role of biological removal in the biogeochemistry of $\mathrm{Al}$ in the SYS.

\section{Materials and methods}

\subsection{Sample collection and shipboard processing}

Two sampling cruises were carried out in the SYS aboard the $R / V$ Bei Dou, 12-19 February 2009, and 24 March to 15 April 2009, respectively (Figure 1(a) and (b)). The latter involved a general survey based on gridded stations 24-30 March, and drifting anchor sampling from 30 March to 15 April. The drifting anchor sampling occurred in an area (Figure 1 (b)) predicted to have a phytoplankton bloom, based on historical information. In situ chlorophyll $a(\mathrm{Chl} a)$ concentrations were measured using in vivo fluorescence to monitor the outbreak of the SPB (Chl $a>4 \mu \mathrm{g} / \mathrm{L}$, [46]). The Chl $a$ concentration in the subsurface layer $(10-20 \mathrm{~m})$ reached $4 \mu \mathrm{g} / \mathrm{L}$ in $\mathrm{Z} 11\left(\mathrm{~B} 20,35^{\circ} 59.761^{\prime} \mathrm{N}, 123^{\circ} 00.356^{\prime} \mathrm{E}\right.$, $72 \mathrm{~m}$ depth) and $\mathrm{Z4}\left(\mathrm{B} 23,35^{\circ} 30.123^{\prime} \mathrm{N}, 124^{\circ} 00.289^{\prime} \mathrm{E}, 83 \mathrm{~m}\right)$ on 4 and 9 April, respectively, which indicated the presence of a bloom. The research vessel followed buoys launched at 03:30 h on 4 April and at 13:42 h on 9 April, Chl $a$ samples were collected every $3 \mathrm{~h}$ and dissolved Al samples were collected every $6 \mathrm{~h}$ until the bloom disappeared. In total, the buoy tracking at Z11and Z4 involved $102 \mathrm{~h}$ and $126 \mathrm{~h}$ of drifting anchor measurement, respectively (Figure $1(\mathrm{c})$ and $(\mathrm{d}))$.

A CTD profile-rosette assembly with Niskin bottles (Model: Sea-Bird 911 ${ }^{\text {plus }}$ ) was used to obtain depth profiles of temperature, salinity, turbidity and fluorescence in the water column at the grid stations. Discrete water samples were taken for $\mathrm{Chl} a$, silicate and $\mathrm{Al}$ analyses were collected at depths determined from the CTD readings. Following collection the samples were filtered through pre-cleaned $0.45 \mu \mathrm{m}$ pore-size cellulose filters (Development Center of Water Treatment Technology, Hangzhou, China; soaked in $\mathrm{HCl}$ solution ( $\mathrm{pH} 2)$ for $24 \mathrm{~h}$ and then in Milli-Q water (Millipore, USA) until a neutral $\mathrm{pH}$ was reached) in a class 100 clean bench. Suspended particulate matter (SPM) was measured by weighing the dried membrane difference before and after filtration. The filtrates obtained on the first cruise were acidified to $\mathrm{pH} 2$ using $\mathrm{HCl}$, and were stored in LDPE bottles in the dark at room temperature. The filtrates obtained on the second cruise were frozen $\left(-20^{\circ} \mathrm{C}\right)$ in LDPE bottles. Blanks were prepared at sea by filtering a known volume of Milli-Q water following the methods used for the seawater samples.

Phytoplankton samples were collected from the Chl $a$ maximum layer at the phytoplankton sampling stations 

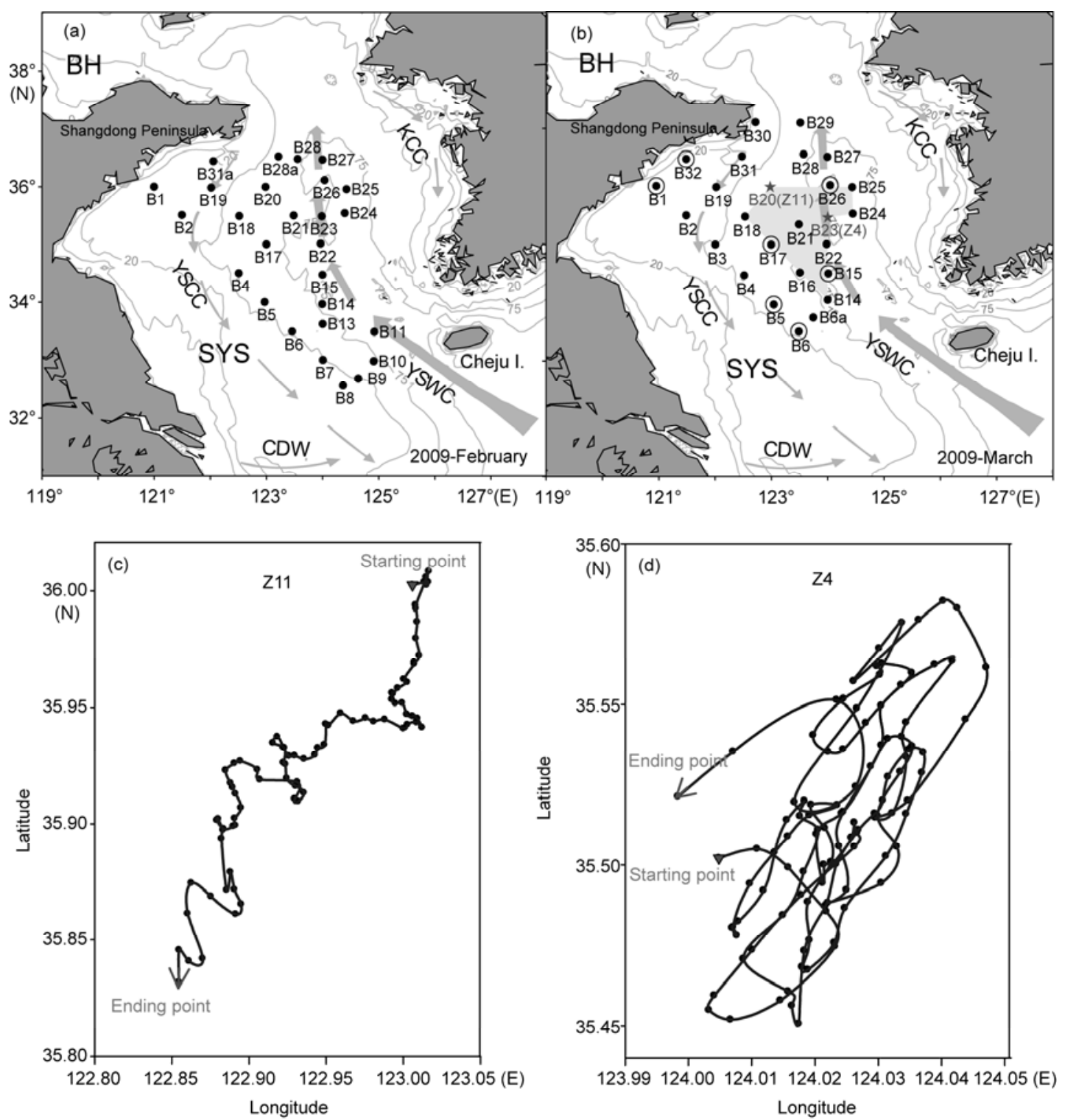

Figure 1 Sampling locations in the southern Yellow Sea. (a) 12-19 February 2009; (b) 24 March-15 April 2009; (c),(d) drifting anchor sampling trajectory conducted at stations Z11 (tracing time $102 \mathrm{~h}$, tracing distance $53.7 \mathrm{~km}$ ) and Z4 (tracing time $126 \mathrm{~h}$, tracing distance $119.2 \mathrm{~km}$ ), respectively. The shadow region in Figure 1(b) is the estimated phytoplankton bloom area; $\star$ drifting anchor stations; $\circ$ phytoplankton sampling stations.

(Figure 1(b)). The samples were filtered through a silk net (200 $\mu \mathrm{m}$ mesh size) to remove zooplankton, then, through a net $(20 \mu \mathrm{m}$ mesh size) to remove fine mineral clay particles. The phytoplankton (four replicates) were removed from the samples onto $0.20 \mu \mathrm{m}$ Whatman polycarbonate filters by filtration under $2-3 \mathrm{kPa}$ atmospheric pressure to avoid damaging the phytoplankton cells. When the volume in the filter tower was reduced to approximately $50 \mathrm{~mL}$, the vacuum pump was turned off and the cells in each of two filter towers were exposed to $50 \mathrm{~mL}$ of oxalate reagent for $5 \mathrm{~min}$, at which time, the vacuum pump was turned back on. The filters were rinsed three times with $5 \mathrm{~mL}$ filtered seawater [39], then frozen until digested to measure Al. The amount of extracellular $\mathrm{Al}$ was calculated as the difference between the mean of two samples that were washed only with filtered seawater, and the mean of the double reagentwashed samples.

\subsection{Analytical method}

In the laboratory, dissolved $\mathrm{Al}$ was determined by fluorescence measurements following complexation with lumogallion and extraction into $n$-hexanol [50]. The silicate concentrations were determined in the laboratory using a Skalar SAN $^{\text {plus }}$ auto analyzer [51]. The Chl $a$ concentration was measured using a Turner Designs 700 fluorometer with the method in the Specifications for Oceanographic Survey (GB/T 12763.4-2007). The membranes supporting filtered phytoplankton cells were digested in $\mathrm{HCl}: \mathrm{HNO}_{3}(3: 1)$ in a closed Teflon system for $30 \mathrm{~h}$ at $170^{\circ} \mathrm{C}$. 


\subsection{Quality assurance/quality control}

The detection limit for dissolved $\mathrm{Al}$ was $0.03 \mathrm{nmol} / \mathrm{L}(3 \sigma)$ with a precision of $1 \%$ at $40 \mathrm{nmol} / \mathrm{L}$ and $6.7 \%$ at $1.0 \mathrm{nmol} / \mathrm{L}$ [50]. Inter-calibrations of dissolved $\mathrm{Al}$ measurements using SAFe and GEOTRACES Atlantic surface and deep water samples showed a difference within 5\% (http://es.ucsc.edu/ kbruland/GeotracesSaFe/kwbGeotracesSaFe.html). The precision of the silicate detection method was $<5 \%$ [51]. The precision $(4.8 \%)$ and recovery $(97 \%-105 \%)$ of the digestion method were tested using Chinese reference materials (CRM, GSD-9). The removal efficiency of the oxalate reagent was determined using cultures of the diatom Thalassi- osira weisslogii, which were processed using the same method as that for the filed-collected phytoplankton samples. For T. weissflogii on washed or not washed membranes, the precision of the total and intra-cellular Al were $3.8 \%$ and $19.3 \%(n=5)$, respectively.

\section{Results}

\subsection{Horizontal distribution of dissolved $\mathrm{Al}$ in the SYS}

The distributions of temperature and salinity in February and March were similar (Figures 2 and 3), and both parameters increased gradually from north to south. The water

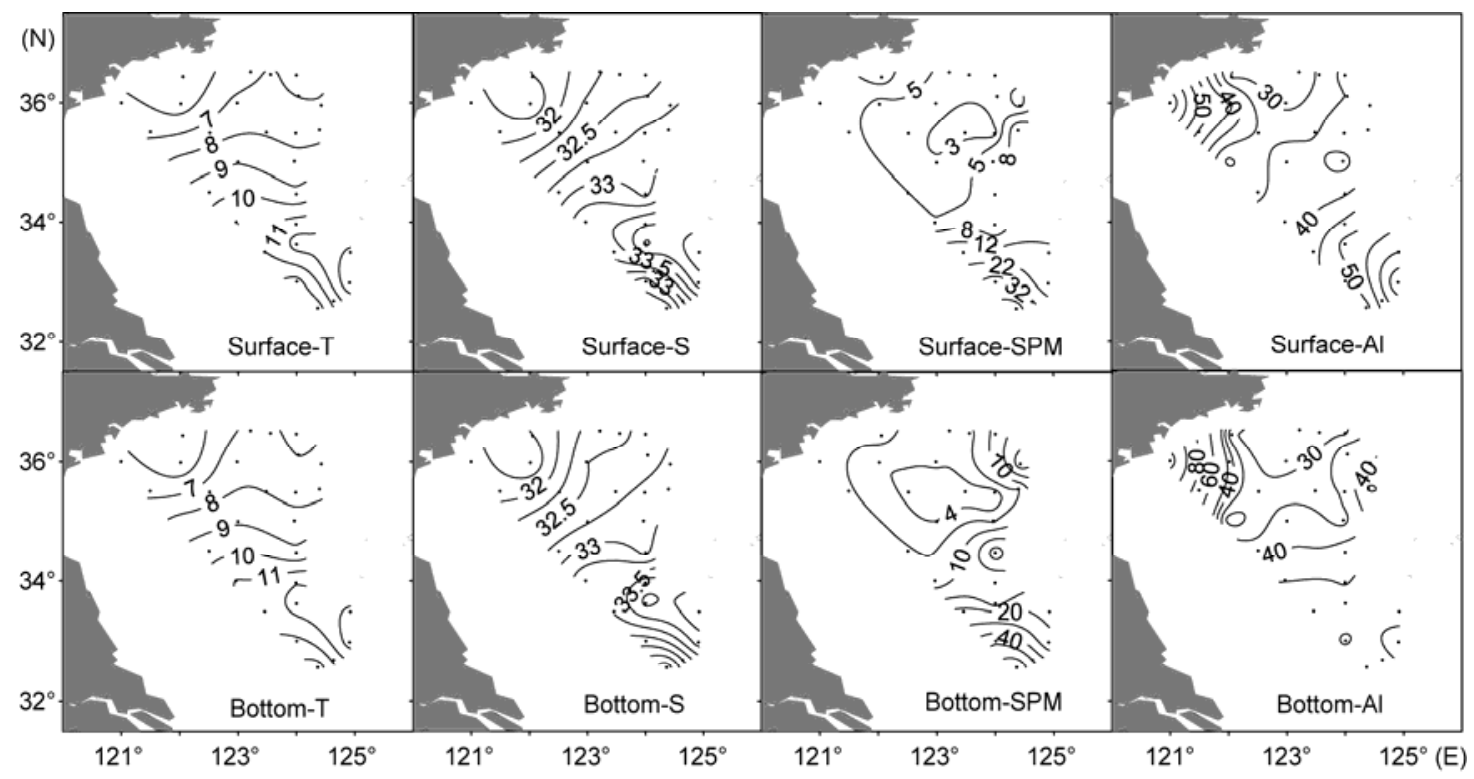

Figure 2 Distributions of temperature $\left({ }^{\circ} \mathrm{C}\right)$, salinity, SPM $(\mathrm{mg} / \mathrm{L})$ and dissolved $\mathrm{Al}(\mathrm{nmol} / \mathrm{L})$ in the surface and near bottom layer in the SYS in February 2009.

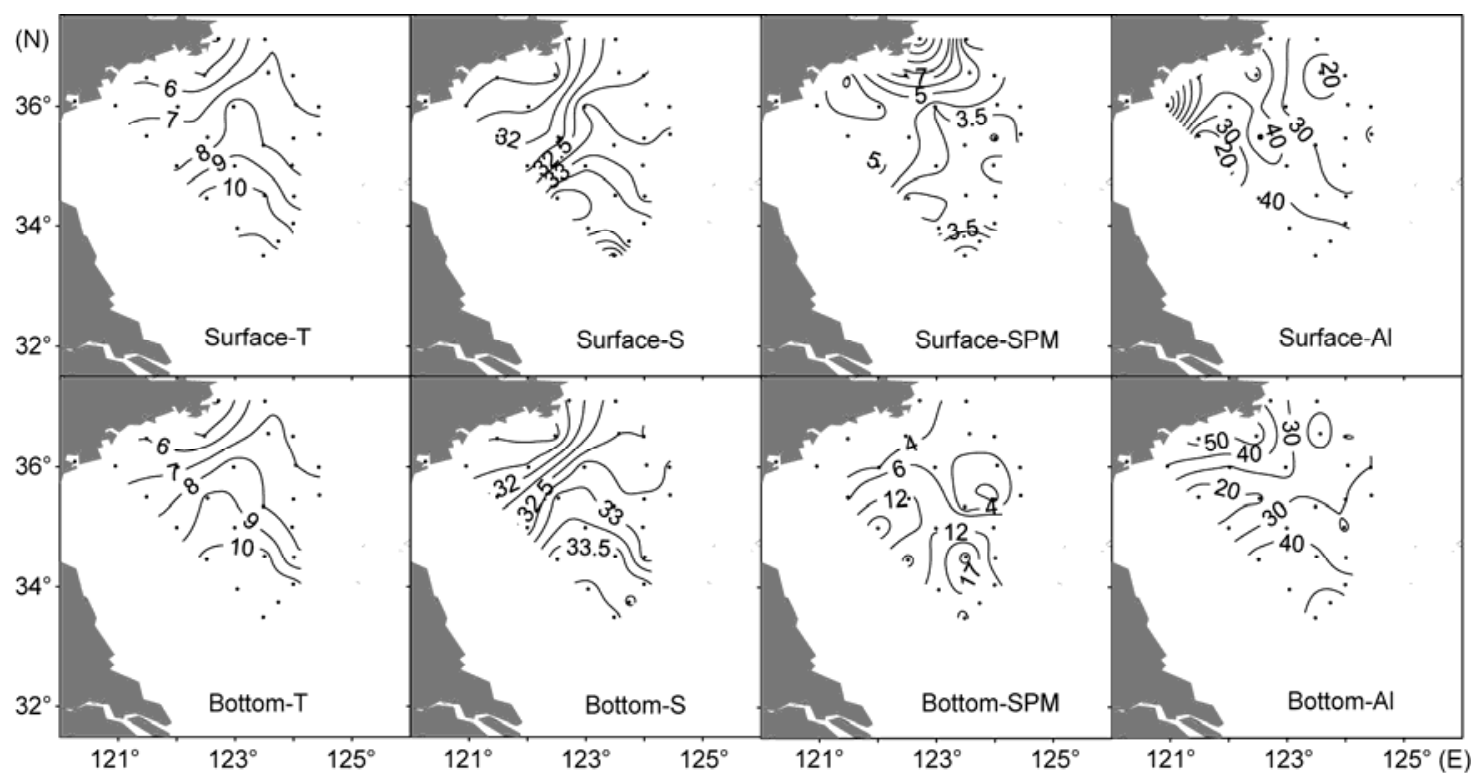

Figure 3 Distributions of temperature $\left({ }^{\circ} \mathrm{C}\right)$, salinity, SPM (mg/L) and dissolved Al (nmol/L) in the surface and near bottom layer in the SYS in March 2009. 
column was well-mixed from the surface to the bottom. There was a water mass characterized by higher temperature and salinity in the southeast of the study area, which may have been caused by intrusion of YSWC [41]. The SPM concentration decreased from nearshore to offshore, and was particularly high at the bottom (Figures 2 and 3). In February the highest SPM values occurred in the southernmost area near the Changjiang estuary, which was associated with input of terrestrial material from Changjiang. The range and mean concentrations of dissolved $\mathrm{Al}$ found in the SYS during the study are summarized in Table 1, which shows that the mean concentration of $\mathrm{Al}$ was higher in February than in March ( $t$-test, $P=0.05)$. The concentration of dissolved $\mathrm{Al}$ decreased gradually from the coastal area to the central SYS, where the lowest concentrations (20-40 $\mathrm{nmol} / \mathrm{L}$ ) were detected. The concentrations of dissolved $\mathrm{Al}$ in the southernmost area reached $40-50 \mathrm{nmol} / \mathrm{L}$ in February, which is consistent with the relatively high concentrations of SPM.

\subsection{Vertical distributions of dissolved Al in the SYS}

The LAT36 section, which transects the central SYS, was used to investigate the vertical distribution of dissolved $\mathrm{Al}$ (Figure 4). It is evident in the vertical profiles of temperature and salinity that the water column was well mixed during both sampling periods. A water mass characterized by high temperature and salinity was detected, which indicated the involvement of the YSWC. The mean temperature and salinity in March were higher than in February. The concentrations of SPM throughout most of area were 3-5 mg/L, suggesting the entire region was well mixed. Higher concentrations of SPM were observed in the layer near the bottom, particularly in February. The concentrations of dissolved $\mathrm{Al}$ were higher in the coastal region, and decreased from nearshore to offshore. In the LAT36 section, the concentrations of dissolved $\mathrm{Al}$ in February were higher than in March, particularly in the coastal area. In the central section there existed a water tongue with low dissolved $\mathrm{Al}$ concentration of $25-35 \mathrm{nmol} / \mathrm{L}$, consistent with the relatively high temperature and salinity.

\subsection{Drifting anchor stations in the SYS}

Figure 5 gave the time-series variations of density (Sigma t),
Chl $a$ and dissolved $\mathrm{Al}$ at Z11 and Z4. As shown in the Figure, during the tracing of drifting anchors with pycnocline of approximately $20 \mathrm{~m}$ and $10 \mathrm{~m}$ at Z11 and Z4, respectively, the water column was stratified obviously. At station Z11, the concentration of $\mathrm{Chl} a$ changed over time; the maximum concentration was found at approximately $60 \mathrm{~h}$, and the concentration declined after $80 \mathrm{~h}$. During the SPB the dominant phytoplankton species at Z11 was the diatom Detonula pumila (unpublished data, Jun Sun). The concentrations of Chl $a$ were high (approximately $3 \mu \mathrm{g} / \mathrm{L}$ ) in the upper layer, especially at the layer approximately $10 \mathrm{~m}$, and then decreased to $<1 \mu \mathrm{g} / \mathrm{L}$ below $30 \mathrm{~m}$. The concentration of dissolved $\mathrm{Al}$ was low in the upper layer, and increased with water depth. The minimum concentration occurred at approcimately $60 \mathrm{~h}$, which corresponded to the maximum Chl $a$ concentration.

At station $\mathrm{Z} 4$ the concentration of $\mathrm{Chl} a$ was highest in the subsurface layer (approximately $20 \mathrm{~m}$ ), and decreased to the bottom. The maximum concentration of $\mathrm{Chl} a$ exceeded $10 \mu \mathrm{g} / \mathrm{L}$, which was higher than at station $\mathrm{Z} 11$, and lasted longer. The dominant phytoplankton species was the dinoflagellate Heterocapsa sp. (unpublished data, Sun Jun). The minimum concentration of dissolved $\mathrm{Al}$ occurred in the subsurface (10-20 m), which was correlated with the maximum concentration of $\mathrm{Chl} a$. At both $\mathrm{Z} 11$ and $\mathrm{Z} 4$ the correlation between the low concentration of dissolved $\mathrm{Al}$ and the high concentration of Chl $a$ indicated that significant scavenging of dissolved $\mathrm{Al}$ occurred during the SPB.

\subsection{Extracellular Al and intracellular Al concentra- tions in phytoplankton}

The phytoplankton samples were washed with oxalate reagent (oxalate-EDTA-citrate) to distinguish extracellular and intracellular $\mathrm{Al}$ associated with the phytoplankton (Figure $6)$. The results showed that the total $\mathrm{Al}$ concentration in phytoplankton was higher in the nearshore stations and decreasd towards the central SYS, with lower value of 8.6 $\mathrm{mg} / \mathrm{g}$ appeared at station B6. However, the highest total Al concentration in phytoplankton was discovered at station B26, located in the central of the SYS, which indicated that the $\mathrm{Al}$ concentration in phytoplankton was influencing by different phytoplankton species rather than the distance from coast. With increasing $\mathrm{Chl} a$ concentration the total $\mathrm{Al}$ concentration in phytoplankton declined rapidly, especially

Table 1 Temperature, salinity, SPM and concentrations of the dissolved Al in SYS

\begin{tabular}{|c|c|c|c|c|c|c|c|c|}
\hline & \multicolumn{4}{|c|}{ February } & \multicolumn{4}{|c|}{ March } \\
\hline & $\mathrm{Al}(\mathrm{nmol} / \mathrm{L})$ & $T\left({ }^{\circ} \mathrm{C}\right)$ & $S$ & $\mathrm{SPM}(\mathrm{mg} / \mathrm{L})$ & $\mathrm{Al}(\mathrm{nmol} / \mathrm{L})$ & $T\left({ }^{\circ} \mathrm{C}\right)$ & $S$ & $\mathrm{SPM}(\mathrm{mg} / \mathrm{L})$ \\
\hline Surface & $26-70$ & $5.3-13.8$ & $31.5-34.2$ & $2.3-46.3$ & $11-102$ & $3.9-10.5$ & $31.4-33.7$ & $2.8-15.9$ \\
\hline \multirow[t]{2}{*}{ Bottom } & $27-128$ & $5.2-13.5$ & $31.5-34.2$ & $3.3-68.7$ & $11-57$ & $3.9-11.0$ & $31.4-33.8$ & $1.5-24.1$ \\
\hline & $42 \pm 12$ & $8.7 \pm 2.4$ & $32.8 \pm 0.7$ & $14.3 \pm 16.4$ & $35 \pm 13$ & $8.0 \pm 1.8$ & $32.7 \pm 0.7$ & $8.9 \pm 6.4$ \\
\hline
\end{tabular}



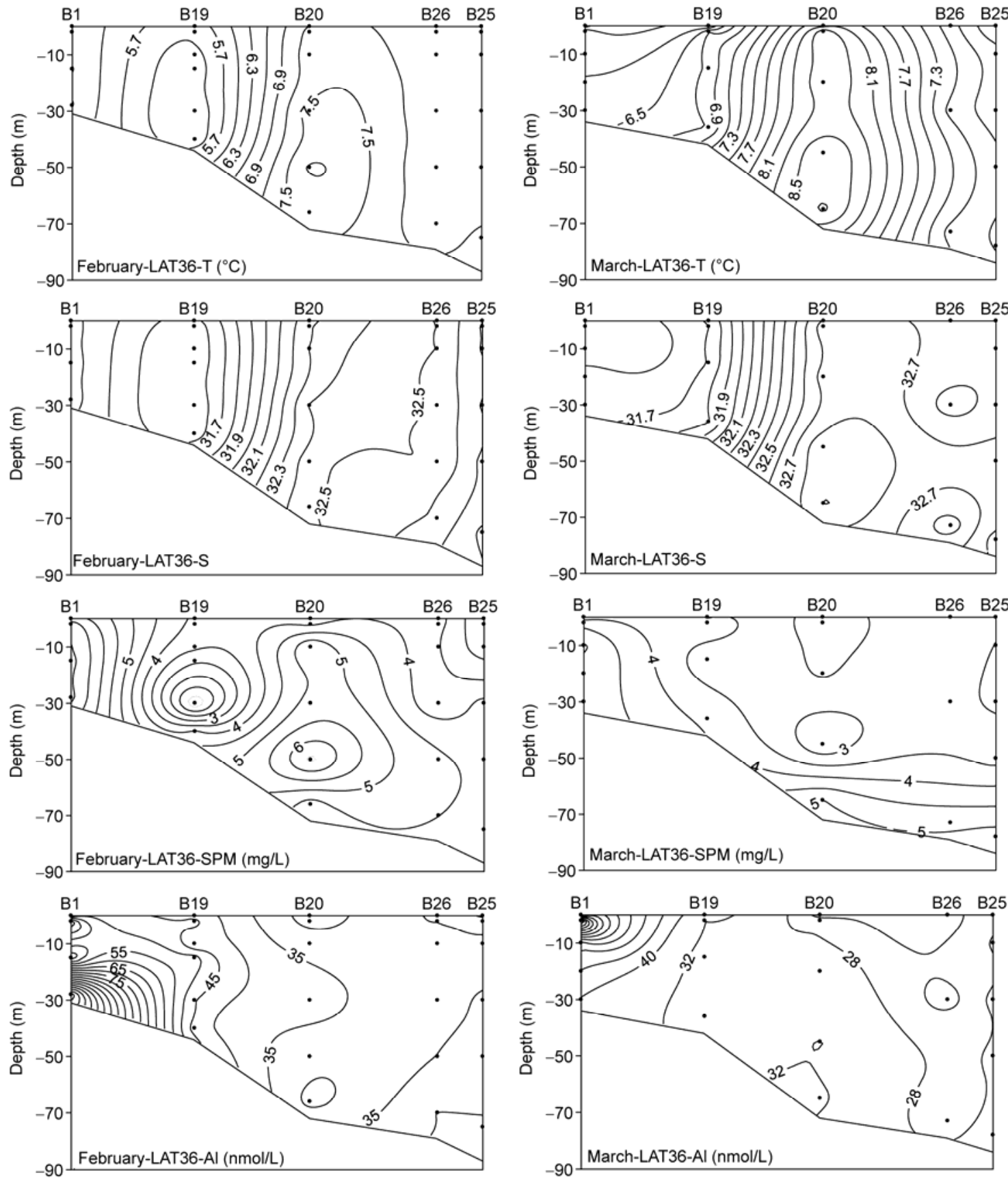

Figure 4 Vertical distributions of temperature $\left({ }^{\circ} \mathrm{C}\right)$, salinity, SPM $(\mathrm{mg} / \mathrm{L})$ and dissolved $\mathrm{Al}(\mathrm{nmol} / \mathrm{L})$ at section LAT36 in the SYS in February and in March 2009.

at station Z4. Similarly, the intracellular concentrations of $\mathrm{Al}$ were low in the central area, but the percent intracellular $\mathrm{Al}$ was high (>80\%, except at B5). The percent of intracellular $\mathrm{Al}$ at most stations exceeded $50 \%$.

\section{Discussions}

\subsection{Influencing factors of the distributions of dissolved Al in the SYS}

Dissolved Al in the seawater mainly derives from the dissolution of weathering products of rocks and soils, with little anthropogenic influence except for the region where is affected by the acid deposition [52]. The concentration of dissolved $\mathrm{Al}$ decreased from the coastal area to the central SYS due to the input of coastal currents, including YSCC and $\mathrm{KCC}$, which carried high dissolved Al concentration water masses from the coastal area [49]. In addition, concentration of dissolved $\mathrm{Al}$ in the bottom was higher than in the surface, especially in the central SYS, consistence with relatively high concentrations of SPM (Figures 2 and 3), which indicated that sediment resuspension was probably 

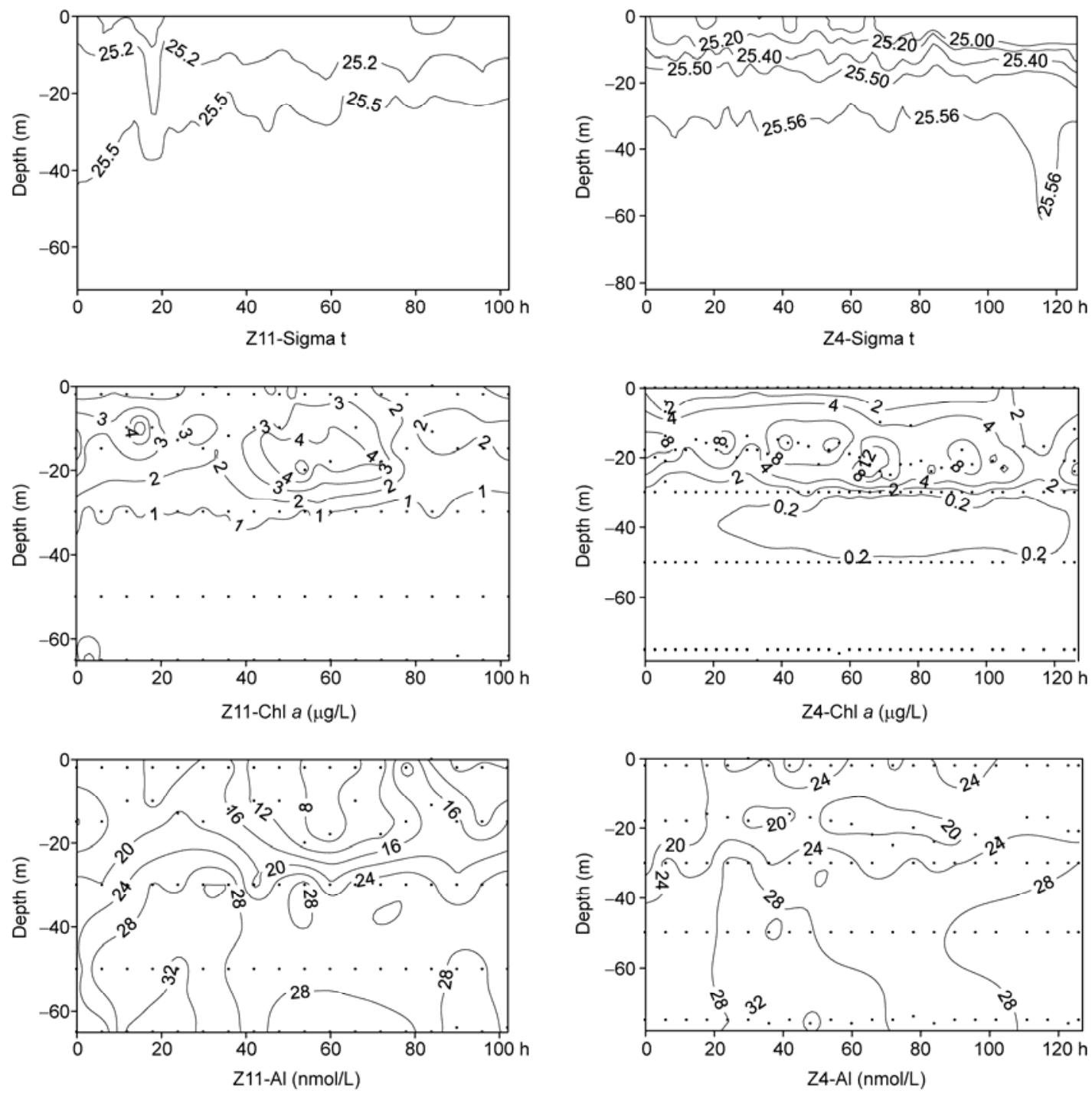

Figure 5 Variations in density (Sigma t), $\mathrm{Chl} a(\mu \mathrm{g} / \mathrm{L})$ and dissolved $\mathrm{Al}(\mathrm{nmol} / \mathrm{L})$ at $\mathrm{Z} 11$ and $\mathrm{Z} 4$ in the SYS during $102 \mathrm{~h}$ and $126 \mathrm{~h}$ time series sampling.

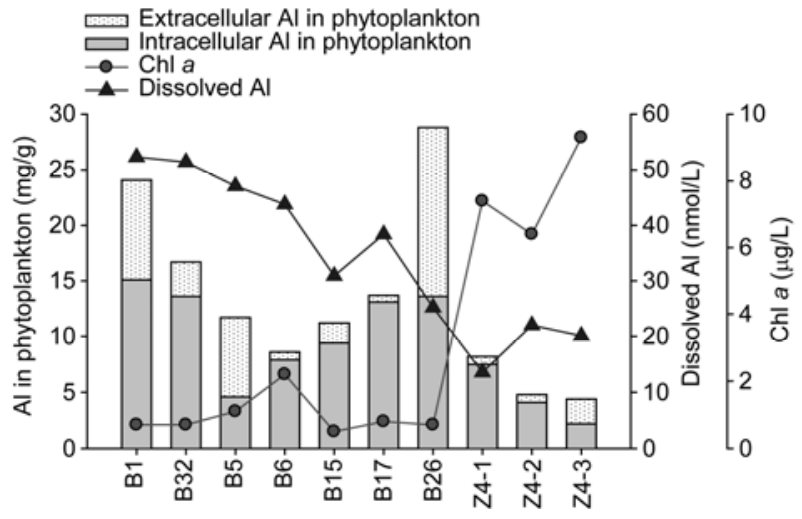

Figure 6 Percentage of extracellular and intracellular Al associated with phytoplankton at the phytoplankton stations (Z4-1, Z4-2, Z4-3 are three periods during the drifting anchor station $\mathrm{Z} 4$, respectively).

the source of dissolved Al close to the bottom [26,27]. There existed a water tongue with lower concentrations
(20-40 nmol/L) of dissolved $\mathrm{Al}$ in the central SYS (Figures 2 and 3 ) and in the central section LAT36 (Figure 4). Incorporation of the distributions of temperature and salinity confirms that the lower concentrations of dissolved $\mathrm{Al}$ are due to the incursion of YSWC, a branch of the Kuroshio Water with relatively low levels of dissolved Al [48].

The central SYS is away from direct influence of rivers, and is mainly influenced by both natural and anthropogenic compounds transported by atmospheric depositions [53]. Huge amounts of terrigenous materials were carried into the SYS by the Asian dust storms which occurred frequently. The concentration of dissolved $\mathrm{Al}$ in the surface of open ocean was controlled by the fractional dissolution of atmospheric dust deposition [22]. However, the atmospheric depositions are seasonal and sporadic. Based on the statistical results, there were three to four dust storm events per year affected the YS [54]. Based on the field observation which was carried in spring 2007 , following an episode of 
enhanced Asian dust storm over the SYS at the beginning of observation, the concentrations of dissolved $\mathrm{Al}$ in the surface were enhanced up to $197 \mathrm{nmol} / \mathrm{L}$ which indicated the influence of dust storm [49]. The estimated atmospheric deposition fluxes of dissolved $\mathrm{Al}$ during the dust storm and the non-dust storm days were $114 \mu \mathrm{mol}$ (Al) $\mathrm{m}^{-2} \mathrm{~d}^{-1}$ and 3.7 $\mu \mathrm{mol}(\mathrm{Al}) \mathrm{m}^{-2} \mathrm{~d}^{-1}$, respectively, based on the field observation carried out in spring 2007 [49]. The atmospheric input of dissolved $\mathrm{Al}$ is 13-fold higher than the sum of riverine inputs in the SYS, although with the characteristics of seasonal and sporadic. During the sampling periods in this study, there was no obviously increased high value of dissolved $\mathrm{Al}$ occurred in the surface layer during the observations in winter and spring 2009, which can indicate the absence of dust storm input. Based on the Micaps meteorology data provided by China Meteorological Administration (CMA), there were four dust events occurred in winter and spring 2009, and only two of them affected the YS, which were occurred during 19-20 February and 14-16 March, respectively. One dust event occurred before the winter cruise, and the other one occurred during the interval between two cruises, which is coincident with no obviously high value of dissolved $\mathrm{Al}$ in the surface during the observations. In brief, the distributions of dissolved $\mathrm{Al}$ in the SYS in winter and spring 2009 were mainly affected by the mixing of different water masses and resuspension of sediments in the bottom, with litter influence from atmospheric depositions. Biological mediation of the behavior of dissolved Al in the SYS was significant and will be discussed in the next section.

\subsection{Biological removal of dissolved $\mathrm{Al}$ in the SYS}

SPBs occur frequently in the SYS, facilitating study of the removal of dissolved Al by phytoplankton. Xuan et al. [46] divided the development of SPB in the SYS into three successive periods: incubation, occurrence and disappearance. March and April are usually the incubation and occurrence periods, respectively, for the SPB in the SYS. Thus, the concentration of dissolved $\mathrm{Al}$ in February can be used as the background value. The concentrations of dissolved Al decreased from $40 \mathrm{nmol} / \mathrm{L}$ in February to $30 \mathrm{nmol} / \mathrm{L}$ in March and to $10-20 \mathrm{nmo} / \mathrm{L}$ in April, while the Chl $a$ concentration increased from $<2 \mu \mathrm{g} / \mathrm{L}$ in March to $>4 \mu \mathrm{g} / \mathrm{L}$ in April. The concentration of dissolved $\mathrm{Al}$ in the SYS decreased significantly with development of the phytoplankton bloom, which indicates that biological scavenging of dissolved Al was occurring.

Figure 7 shows the vertical profiles of dissolved $\mathrm{Al}, \mathrm{Chl}$ $a$ and other parameters at stations Z11 and Z4. A thermocline and a halocline developed at 10-20 m, and the maximum concentration of Chl $a$ was found below these layers. The concentration of silicate in the upper layer was depleted significantly at station $\mathrm{Z} 11$, while this was not the case at station Z4. The different vertical profiles of silicate at the two drift stations during the SPB were probably a result of different dominant phytoplankton species, with Detonula pumila at station Z11 and Heterocapsa sp. at station Z4. The vertical profiles of dissolved Al showed lower values in the upper layer and higher values in near the bottom layer, which was a similar pattern to that of silicate. The lowest
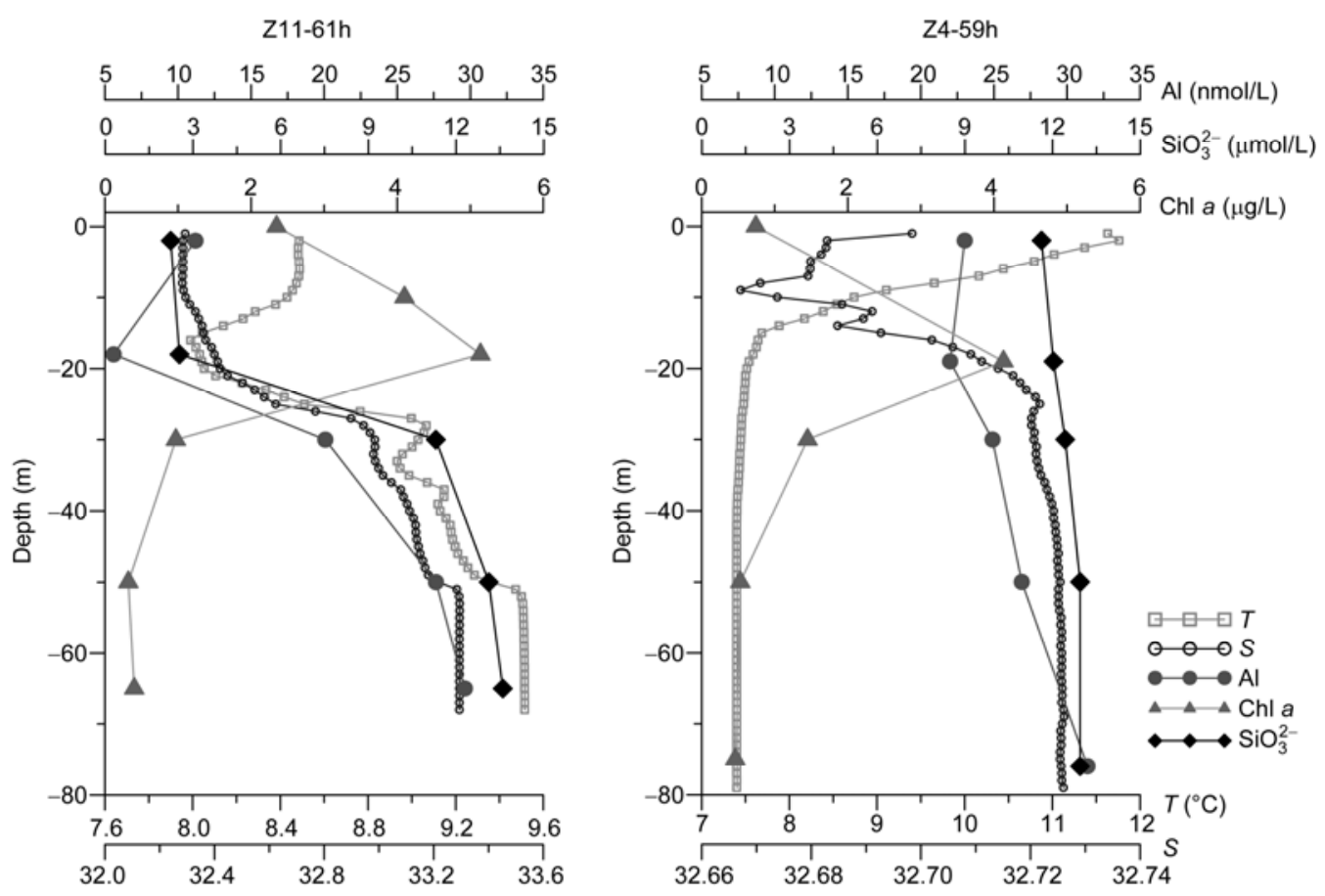

Figure 7 Vertical profiles of temperature, salinity, dissolved $\mathrm{Al}$ and $\mathrm{Chl} a$ at stations $\mathrm{Z} 11$ and $\mathrm{Z} 4$ during the drifting anchor sampling. 
concentration of dissolved $\mathrm{Al}$ coincided with the layer of maximum Chl $a$ concentration at both stations, which further indicated biological removal of dissolved $\mathrm{Al}$ in the SYS.

However, the removal efficiency of dissolved Al was much lower at station Z4 than at station Z11, although the concentration of Chl $a$ was almost three-fold higher at the former (Figure 8); this indicates that the biological scavenging of dissolved $\mathrm{Al}$ at station $\mathrm{Z} 11$ was more significant. Figure 8 showed the relationship between the concentrations of dissolved $\mathrm{Al}$ and $\mathrm{Chl} a$ in the subsurface layer (Chl $a$ maximum layer) at stations Z11 and Z4. The slopes of the lines showing the Al-Chl $a$ relationship in the subsurface waters at stations Z11 and Z4 were -4.49 and 0.25 , respectively. The relationship between the dissolved $\mathrm{Al}$ and $\mathrm{Chl} a$ concentrations suggested significant biological removal of $\mathrm{Al}$ at $\mathrm{Z} 11(P<0.005, n=15)$, but not at station $\mathrm{Z} 4$. This may have been because of the different phytoplankton species dominating the SPB at each location. Detonula pumila (diatom) and Heterocapsa sp. (Dinoflagellates) dominated the SPB at stations Z11 and Z4 respectively, indicating that Detonula pumila can scavenge dissolved Al much more effectively. Li et al. [55] also reported that dissolved Al in the coastal area of Zhejiang and Fujian (China) was removed mainly by Skeletonema costatum (diatom), ranther than by dinoflagellates. Many studies [18,36,37,56] have shown that dissolved $\mathrm{Al}$ can be taken up by diatoms, but there have been few studies of this process among dinoflagellates. The relationship between phytoplankton species and dissolved $\mathrm{Al}$ removal requires further study.

\subsection{Preliminary assessment of the mechanism of bio- logical removal of dissolved $\mathrm{Al}$ in the SYS}

The trace metal clean reagent provides the means to distinguish between extracellular and intracellular Al in phytoplankton, and to investigate the biological mechanisms of Al removal. As shown in Figure 6, the range of total $\mathrm{Al}$ concentrations associated with phytoplankton was 4.4-48.6 $\mathrm{mg} / \mathrm{g}$, and for the intracellular percentage was 39\%-96\%.

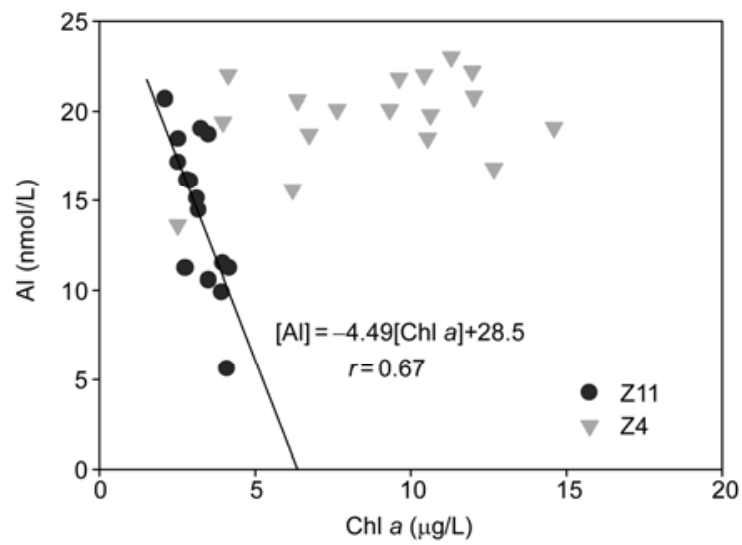

Figure 8 Relationship between dissolved $\mathrm{Al}$ and $\mathrm{Chl} a$ in the subsurface layer (Chl $a$ maximum layer) at stations $\mathrm{Z} 11$ and $\mathrm{Z} 4$.
There was a negative correlation between the concentrations of total $\mathrm{Al}$ and $\mathrm{Chl} a(P<0.05, n=10)$. The concentration of total $\mathrm{Al}$ in phytoplankton decreased with increasing of Chl $a$ concentration, which was caused by the dilution effect of phytoplankton proliferation.

The mean percentage of intracellular $\mathrm{Al}$ was $73 \% \pm 21 \%$, which suggests that most of the scavenged Al was absorbed by phytoplankton during the SPB. Previous studies based on limited observational data $[36,49]$ have indicated that the concentration of dissolved $\mathrm{Al}$ is lowest following decline of the SPB. In this study, sampling at the drifting anchor stations occurred over a period of more than $100 \mathrm{~h}$, and showed that the minimum concentration of dissolved $\mathrm{Al}$ coincided with the maximum of $\mathrm{Chl} a$ concentration (Figures 5 and 7). This indicates that the dissolved $\mathrm{Al}$ was scavenged by absorption during biological activity, which was reflected in the high intracellular percentage of Al. Thus, biological absorption was the major mechanism associated with scavenging of dissolved $\mathrm{Al}$ during this investigation.

However, there were several uncertainties in the use of the oxalate reagent method for differentiating surface adsorption and internal pools of $\mathrm{Al}$ in phytoplankton. Firstly, the removal efficiency of the oxalate reagent was not tested because of the lack of an effective isotopic tracer for $\mathrm{Al}$. Secondly, during sample preparation we assumed that all the filtered particles were phytoplankton, but some fine clay particles may have been retained rather than having been removed during the collection of phytoplankton samples by filtrate through $20 \mu \mathrm{m}$ mesh net. Thus, the intracellular Al percentages may be overestimates, especially those from nearshore stations where the SPM concentrations were relatively high. To assess the reliability of the field data with respect to the percentage intracellular $\mathrm{Al}$ in phytoplankton, laboratory incubation experiments were conducted using a range of diatoms (Nitzschia closterium, Skeletonema costatum, Thalassiosira weissflogii) and the dinoflagellate Prorocentrum donghaiense under various $\mathrm{Al}$ enrichment conditions. During the incubation experiments, we used the filtered and sterilized seawater, so in this system there was no interference by clay particles. The results showed that the dissolved Al concentrations decreased significantly during exponential growth of the diatoms, but only decreased slightly during growth of the dinoflagellate. The percentage of intracellular $\mathrm{Al}$ was approximately $30 \%-80 \%$, and varied with growth phase (unpublished data). The combined results of the field study and incubation experiments, confirm that active absorption of dissolved $\mathrm{Al}$ by diatom species occurs. More laboratory incubation experiments and field measurements are needed to clarify the mechanism of biological removal of dissolved Al.

\section{Conclusions}

This study investigated the dissolved Al concentration in 
winter and spring in the SYS. The concentrations in February, March, and April were $42 \pm 14 \mathrm{nmol} / \mathrm{L}, 34 \pm 13 \mathrm{nmol} / \mathrm{L}$, and $23 \pm 7 \mathrm{nmol} / \mathrm{L}$, respectively. Significant scavenging of dissolved $\mathrm{Al}$ occurred during the SPB, which indicates that removal of dissolved $\mathrm{Al}$ in the study area was biologically mediated. The results of drifting anchor sampling indicated that the removal of dissolved $\mathrm{Al}$ differed between diatoms and dinoflagellate, with the diatoms having much higher removal efficiency. To understand the mechanism of biological removal of $\mathrm{Al}$, washing with the trace metal clean reagent was used to distinguish between the extracellular and intracellular pool associated with the phytoplankton. This showed that the intracellular pool accounted for most of the phytoplankton associated $\mathrm{Al}$, indicating that biological absorption was the predominant mechanism of biological scavenging of dissolved Al during the SPBs investigated.

This work was supported by the National Basic Research Program of Science and Technology of China (2011CB409801) and the National Natural Science Foundation of China (41176096). The authors thank the captain and crew of $R / V$ Bei Dou for sample collection during the field programs and Drs. D. J. Huang, J. Sun and J. H. Shi for providing hydrographic, phytoplankton species identification and dust deposition data. Colleagues of the Marine Biogeochemistry Laboratory in the Ocean University of China are acknowledged for assistance during the field and laboratory studies. The anonymous reviewers and English editor are greatly acknowledged, as their comments improved the original manuscript greatly.

1 Orians K J, Bruland K W. Dissolved aluminum in the Central North Pacific. Nature, 1985, 316: 427-429

2 Orians K J, Bruland K W. The biogeochemistry of aluminum in the Pacific Ocean. Earth Planet Sci Lett, 1986, 78: 397-410

3 Measures C I, Brown M T, Vink S. Dust deposition to the surface waters of the western and central North Pacific inferred from surface water dissolved aluminum concentrations. Geochem Geophy Geosyst, 2005, Q09M03, doi: 10.1029/2005GC000922

4 Kaupp L J, Measures C I, Selph K E, et al. The distribution of dissolved $\mathrm{Fe}$ and $\mathrm{Al}$ in the upper waters of the Eastern Equatorial Pacific. Deep-Sea Res II, 2011, 58: 296-310

5 Measures C I. The distribution of $\mathrm{Al}$ in the IOC stations of the eastern Atlantic between $30^{\circ} \mathrm{S}$ and $34^{\circ} \mathrm{N}$. Mar Chem, 1995, 49: 267-281

6 Hall I R, Measures C I. The distribution of Al in the IOC stations of the North Atlantic and Norwegian Sea between $52^{\circ}$ and $65^{\circ}$ North. Mar Chem, 1998, 61: 69-85

7 Vink S, Measures C I. The role of dust deposition in determining surface water distributions of $\mathrm{Al}$ and $\mathrm{Fe}$ in the South West Atlantic. Deep-Sea Res II, 2001, 48: 2787-2809

8 Kramer J, Laan P, Sarthou G, et al. Distribution of dissolved aluminum in the high atmospheric input region of the subtropical waters of the North Atlantic Ocean. Mar Chem, 2004, 88: 85-101

9 Upadhyay S, Gupta R S. Aluminum in the northwestern Indian Ocean (Arabian Sea). Mar Chem, 1994, 47: 203-214

10 Measures C I, Vink S. Seasonal variations in the distribution of Fe and $\mathrm{Al}$ in the surface waters of the Arabian Sea. Deep-Sea Res II, 1999, 46: 1597-1622

11 Obata H, Nozaki Y, Alibo D S, et al. Dissolved Al, In, and Ce in the eastern Indian Ocean and the Southeast Asian Seas in comparison with the radionuclides ${ }^{210} \mathrm{~Pb}$ and ${ }^{210} \mathrm{Po}$. Geochim Cosmochim Acta, 2004, 68: 1035-1048

12 Moran S B, Moore R M. Kinetics of the removal of dissolved aluminum by diatoms in seawater: A comparison with thorium. Geochim cosmochim acta, 1992, 56: 3365-3374

13 Measures C I. The role of entrained sediments in sea ice in the dis- tribution of aluminum and iron in the surface waters of the Arctic Ocean. Mar Chem, 1999, 68: 59-70

14 Middag R, de Baar H J W, Laan P, et al. Dissolved aluminum and the silicon cycle in the Arctic Ocean. Mar Chem, 2009, 115: 176-195

15 Hendry K R, Meredith M P, Measures C I, et al. The role of sea ice formation in cycling of aluminum in northern Marguerite Bay, Antarctica. Estuar Coast Shelf Sci, 2010, 87: 103-112

16 Hydes D J, De Lange G J, De Baar H. Dissolved aluminum in the Mediterranean. Geochim Cosmochim Acta, 1988, 52: 2107-2114

17 Measures C I, Edmond J M. Aluminum as a tracer of the deep outflow from the Mediterranean. J Geophy Res, 1988, 93: 591-595

18 Chou L, Wollast R. Biogeochemical behavior and mass balance of dissolved aluminum in the western Mediterranean Sea. Deep-Sea Res II, 1997, 44: 741-768

19 Maring H B, Duce R A. The impact of atmospheric aerosols on trace metal chemistry in open ocean surface seawater, 1. Aluminum. Earth Planet Sci Lett, 1987, 84: 381-392

20 Prospero J M, Ruby T N, Mitsuo U. Deposition rate of particulate and dissolved aluminum derived from Saharan Dust in precipitation at Miami, Florida. J Geophy Res, 1987, 92: 14723-14731

21 Jeroen T M de Jong, Marie B, Maria D G C. Inputs of iron, manganese and aluminum to surface waters of the Northeast Atlantic Ocean and the European continental shelf. Mar Chem, 2007, 107: 120-142

22 Measures C I, Sato T, Vink S, et al. The fractional solubility of aluminum from mineral aerosols collected in Hawaii and implications for atmospheric deposition of biogeochemically important trace elements. Mar Chem, 2010, 120: 144-153

23 Hydes D J, Liss P S. The behavior of dissolved aluminum in estuarine and coastal waters. Estuar Coast Mar Sci, 1977, 5: 755-769

24 Morris A W, Howland R J M, Bale A J. Dissolved aluminum in the Tamar estuary, southeast England. Geochim Cosmochim Acta, 1986, 50: 89-197

25 Hydes D J. Seasonal variation in dissolved aluminum concentrations in coastal waters and biological limitation of the export of the riverine input of aluminum to the deep sea. Cont Shelf Res, 1989, 9: 919-929

26 Mackin J E, Aller R C. Dissolved Al in sediments and waters of the East China Sea: Implications for authigenic mineral formation. Geochim Cosmochim Acta, 1984, 48: 281-297

27 Moran S B, Moore R M. The potential source of dissolved aluminum from resuspended sediments to the North Atlantic Deep Water. Geochim Cosmochim Acta, 1991, 55: 2745-2751

28 Measures C I, Brown E T. Estimating dust input to the Atlantic Ocean using surface water Al concentrations. In: Guerzoni S, Chester R, eds. The Impact of Desert Dust Across the Mediterranean. Kluwer, Dordrecht, 1996, 301-311

29 Measures C I, Vink S. On the use of dissolved aluminum in the surface waters to estimate dust deposition to the ocean. Global Biogeochem Cycles, 2000, 14: 317-327

30 Gehlen M, Heinze C, Maier-Reimer E, et al. Coupled Al-Si geochemistry in an ocean general circulation model: A tool for the validation of oceanic dust deposition fields? Global Biogeochem Cycles, 2003, 17: 1028

31 Han Q, Moore J K, Zender C, et al. Constraining oceanic dust deposition using surface ocean dissolved Al. Global Biogeochem Cycles, 2008, 22, GB2003, doi:10.1029/2007GB002975

32 Upadhyay S. Sorption model for dissolved and particulate aluminum in the Conway estuary, UK. Estuar Coast Shelf Sci, 2008, 76: 914-919

33 Hall I R, Hydes D J, Statham P J, et al. Seasonal variations in the cycling of aluminum, cadmium and manganese in a Scottish sea loch: Biogeochemical processes involving suspended particles. Cont Shelf Res, 1999, 19: 1783-1808

34 Moran S B, Moore R M. Evidence from mesocosm studies for biological removal of dissolved aluminum from sea water. Nature, 1988, 335: 706-708

35 Moran S B, Moore R M. Temporal variations in dissolved and particulate aluminum during a spring bloom. Estuar Coast Shelf Sci, 1988, 27: $205-215$ 
36 Moran S B, Moore R M, Westerlund S. Dissolved aluminum in the Weddell Sea. Deep-Sea Res, 1992, 39: 537-547

37 Gehlen M, Beck L, Calas G, et al. Unraveling the atomic structure of biogenic silica: Vidence of the structural association of $\mathrm{Al}$ and $\mathrm{Si}$ in diatom frustules. Geochim Cosmochim Acta, 2002, 66: 1601-1609

38 Hudson R J M, Morel F M M. Distinguishing between extra- and intracellular iron in marine phytoplankton. Limnol Oceanogr, 1989, 34: 1113-1120

39 Tovar-Sanchez A, Saņudo-Wilhelmy S A, Garcia-Vargas M, et al. A trace metal clean reagent to remove surface-bound iron from marine phytoplankton. Mar Chem, 2003, 82: 91-99

40 Su J. Circulation dynamics of the China Seas North of $18^{\circ}$ N. In: Robinson A R, Brink K H, eds. The Sea. New York: Wiley, 1998, 11: 483-505

41 Xu L L, Wu D X, Lin X P, et al. The study of the Yellow Sea warm current and its seasonal variability. J Hydro, 2009, 21: 159-165

42 Wei H H, Wang L, Lin Y A, et al. Nutrient transport across the thermocline in the central yellow sea. Adv Mar Sci, 2002, 20: 15-20

43 Weng X C, Zhang Y K, Wang C M, et al. The variational characteristics of the huanghai sea (Yellow Sea) cold water mass. J Ocean Univ China, 1989, 19: 11-131

44 Liu S M, Zhang J, Chen S Z, et al. Inventory of nutrient compounds in the Yellow Sea. Cont Shelf Res, 2003, 23: 1161-1174

45 Yang S Y, Jung H J, Lim D I, et al. A review on the provenance discrimination of sediments in the Yellow Sea. Earth-Sci Rev, 2003, 63: 93-120

46 Xuan J L, Zhou F, Huang D J, et al. Physical processes and their role on the spatial and temporal variability of the spring phytoplankton bloom in the central Yellow Sea. Acta Ecolog Sin, 2011, 31: 61-70

47 Lin C, Ning X, Su J, et al. Environmental changes and the responses of the ecosystems of the Yellow Sea during1976-2000. J Mar Syst, 2005, 55: 223-234

48 Ren J L, Zhang G L, Zhang J, et al. Distribution of dissolved aluminum in the Southern Yellow Sea: Influences of a dust storm and the spring bloom. Mar Chem, 2011, 125: 69-81

49 Ren J L, Zhang J, Li J B, et al. Dissolved aluminum in the Yellow Sea and East China Sea-Al as a tracer of Changjiang (Yangtze River) discharge and Kuroshio incursion. Estuar Coast Shelf Sci, 2006, 68: $165-174$

50 Zhang J, Xu H, Ren J L. Fluorimetric determination of dissolved aluminum in natural waters after liquid-liquid extraction into n-hexanol. Anal Chim Acta, 2000, 405: 31-42

51 Liu S M, Zhang J, Chen H T, et al. Factors influencing nutrient dynamics in the eutrophic Jiaozhou Bay, North China. Prog Oceanogra, 2005, 66: 66-85

52 Nelson W O, Campell P G C. The effects of acidification on the geochemistry of $\mathrm{Al}, \mathrm{Cd}, \mathrm{Pb}$ and $\mathrm{Hg}$ in freshwater environment: A literature review. Environ Pollut, 1991, 71: 91-130

53 Zhang J, Liu M G. Observations of nutrient elements and sulphate in atmospheric wet depositions over the Northwest pacific coastal oceans-Yellow Sea. Mar Chem, 1994, 47:173-189

54 Zhang K, Gao H W. The characteristics of Asian-dust storms during 2000-2002: From the source to the sea. Atmos Environ, 2007, 41: 9136-9145

55 Li F M, Ren J L, Zhang G L, et al. The distribution of dissolved aluminum in the coastal area of Zhejiang and Fujian (in Chinese). Acta Oceanol Sin, 2012, 34: 63-72

56 Koning E, Gehlen M, Flank A M, et al. Rapid post-mortem incorporation of aluminum in diatom frustules: Evidence from chemical and structural analyses. Mar Chem, 106: 208-222

Open Access This article is distributed under the terms of the Creative Commons Attribution License which permits any use, distribution, and reproduction in any medium, provided the original author(s) and source are credited. 